\title{
Significant increase of surface ozone at a rural site, north of eastern China
}

\author{
Zhiqiang Ma ${ }^{1,2}$, Jing Xu${ }^{1,2}$, Weijun Quan ${ }^{2}$, Ziyin Zhang ${ }^{2}$, Weili Lin ${ }^{3}$, and Xiaobin $\mathrm{Xu}^{4}$ \\ ${ }^{1}$ Institute of Urban Meteorology, China Meteorological Administration, Beijing, China \\ ${ }^{2}$ Environmental Meteorology Forecast Center of Beijing-Tianjin-Hebei, Chinese Meteorological Administration, \\ Beijing, China \\ ${ }^{3}$ Meteorological Observation Centre, China Meteorological Administration, Beijing, China \\ ${ }^{4}$ Key Laboratory for Atmospheric Chemistry of CMA, Chinese Academy of Meteorological Sciences, \\ Beijing, China
}

Correspondence to: Weili Lin (linwl@camscma.cn)

Received: 6 September 2015 - Published in Atmos. Chem. Phys. Discuss.: 13 November 2015

Revised: 11 March 2016 - Accepted: 14 March 2016 - Published: 24 March 2016

\begin{abstract}
Ozone pollution in eastern China has become one of the top environmental issues. Quantifying the temporal trend of surface ozone helps to assess the impacts of the anthropogenic precursor reductions and the likely effects of emission control strategies implemented. In this paper, ozone data collected at the Shangdianzi (SDZ) regional atmospheric background station from 2003 to 2015 are presented and analyzed to obtain the variation in the trend of surface ozone in the most polluted region of China, north of eastern China or the North China Plain. A modified KolmogorovZurbenko (KZ) filter method was performed on the maximum daily average $8 \mathrm{~h}$ (MDA8) concentrations of ozone to separate the contributions of different factors from the variation of surface ozone and remove the influence of meteorological fluctuations on surface ozone. Results reveal that the short-term, seasonal and long-term components of ozone account for $36.4,57.6$ and $2.2 \%$ of the total variance, respectively. The long-term trend indicates that the MDA8 has undergone a significant increase in the period of 2003-2015, with an average rate of $1.13 \pm 0.01$ ppb year $^{-1}\left(R^{2}=0.92\right)$. It is found that meteorological factors did not significantly influence the long-term variation of ozone and the increase may be completely attributed to changes in emissions. Furthermore, there is no significant correlation between the longterm $\mathrm{O}_{3}$ and $\mathrm{NO}_{2}$ trends. This study suggests that emission changes in VOCs might have played a more important role in the observed increase of surface ozone at SDZ.
\end{abstract}

\section{Introduction}

Tropospheric ozone $\left(\mathrm{O}_{3}\right)$ plays a key role in the oxidizing capacity of the atmosphere (Penkett, 1988) and acts as a greenhouse gas in terms of radiative forcing at the Earth's surface (IPCC, 2013). Moreover, it is an important precursor of the $\mathrm{OH}$ radical, hence changes in its abundance can exert indirect radiative forcing by altering the lifetimes of some other greenhouse gases. Tropospheric $\mathrm{O}_{3}$ originates from photochemical production within the troposphere and the downward transport of stratospheric $\mathrm{O}_{3}$ (Cooper et al., 2014; Monks et al., 2015). Ground-level $\mathrm{O}_{3}$ is subject to in situ chemical reactions and physical processes and is directly affected by precursor emissions, temperature, solar radiation and other meteorological factors.

Observations (Oltmans et al., 2006) and model simulations (Hauglustaine and Brasseur, 2003) indicate that ground-level $\mathrm{O}_{3}$ increased distinctly at northern mid-latitudes during the latter half of the 20th century, which is qualitatively in agreement with the increasing anthropogenic emissions of precursors. Anthropogenic emissions of $\mathrm{O}_{3}$ precursors have been declining in Europe and North America while increasing in East Asia (Streets et al., 2001; Granier et al., 2011). The largest increase in $\mathrm{NO}_{x}\left(\mathrm{NO}+\mathrm{NO}_{2}\right)$ emissions is found in China and appears to have continued into the 21st century based on emission inventories (Streets et al., 2001; Richter et al., 2005; Ohara et al., 2007; Mijling et al., 2013; Kurokawa et al., 2013). From 1990 to 2010, surface $\mathrm{O}_{3}$ in different regions showed inconsistent trends. In the eastern US, sur- 
face $\mathrm{O}_{3}$ was found to decrease strongly in summer, remain largely unchanged in spring and increase in winter, while $\mathrm{O}_{3}$ increases in the western US were the strongest in spring (Monks et al., 2015). In East Asia, surface $\mathrm{O}_{3}$ was generally found to be increasing (Cooper et al., 2014). For example, ground-level $\mathrm{O}_{3}$ in the Northeast Asia region, e.g., Japan (Lee et al., 1998) and Hong Kong (Chan et al., 2003; Wang et al., 2009) increased significantly from the 1990s to 2000s. Enhanced variability of surface $\mathrm{O}_{3}$, particularly an increasing trend in the monthly highest $5 \%$ of the ozone mixing ratios, was reported for the Yangtze River Delta region in eastern China (Xu et al., 2008).

Dynamic factors may contribute to the long-term variations of surface $\mathrm{O}_{3}$. For example, the long-term increase of surface $\mathrm{O}_{3}$ was found to be related to the variability in the stratosphere-to-troposphere transport of $\mathrm{O}_{3}$ (Ordonez et al., 2007; Hess and Zbinden, 2013; Lin et al., 2015a) and changes in transport patterns (Pausata et al., 2012). Decadal circulation shifts played a key role in the autumnal ozone increase and the absence of spring ozone change measured at the Mauna Loa Observatory ( $3.4 \mathrm{~km}$ altitude) over the subtropical Pacific Ocean in the period of 1974-2012 (Lin et al., 2014). However, some studies (Brown-Steiner and Hess, 2011; Parrish et al., 2012; Lin et al., 2012; Oltmans et al., 2013; Derwent et al., 2015; Verstraeten et al., 2015) attribute the increase of $\mathrm{O}_{3}$ in some areas mainly to the transport of $\mathrm{O}_{3}$ and related pollutants from the continental China, where the emissions of $\mathrm{O}_{3}$ precursors $\left(\mathrm{NO}_{x}\right.$ and VOC) have steadily increased (Ohara et al., 2007; Kurokawa et al., 2013). Studies by Lin et al. (2015b) indicate that mean springtime ozone level over western North America in the most recent decade has increased by $5.9 \pm 2.1 \mathrm{ppbv}$ compared to the $1980 \mathrm{~s}$, which could be attributed in part to rising Asian ozone precursor emissions and global methane. Because of increasing emissions of $\mathrm{O}_{3}$ precursors due to the sustained economic growth in China (Zhang et al., 2007), fueled by favorable photochemical conditions, China has likely being experiencing severe photochemical pollution. Due to this industrialization, increases are expected in some regions. Limited studies have indicated this is indeed the case. Ding et al. (2008) analyzed $\mathrm{O}_{3}$ data from the MOZAIC (measurement of ozone and water vapor by Airbus in-service aircraft) program and obtained a $2 \%$ year $^{-1}$ rate of increase in the daytime $\mathrm{O}_{3}$ in the lower troposphere over Beijing and its surrounding areas for the period of 1995-2005. Xu and Lin (2011) analyzed the TOR (tropospheric ozone residue) data over the period 19792005 and found a significant upward trend in tropospheric $\mathrm{O}_{3}$ over the North China Plain for all seasons except for winter, with a maximum rate of increase of 1.10 DU per decade for summer. Wang et al. (2009) found that surface $\mathrm{O}_{3}$ at a regional station in Hong Kong increased at an average rate of 0.58 ppb year $^{-1}$ from 1994 to 2007 and they associated the trend with an increase in tropospheric $\mathrm{NO}_{2}$.

Information regarding the trends in surface $\mathrm{O}_{3}$ concentrations in the different regions of China, particularly those with high anthropogenic emissions rates, is urgently needed. Due to a lack of long-term observations, it is difficult to gain reliable results about the long-term trends of surface $\mathrm{O}_{3}$ in various regions of China. Recently, the long-term trend of surface $\mathrm{O}_{3}$ in western China was reported by Xu et al. (2015), based on the observations at the Mt. Waliguan baseline station. So far, there has been no report of changes of surface $\mathrm{O}_{3}$ levels in highly polluted eastern China during the recent decade. In this paper, we present trends in surface $\mathrm{O}_{3}$ in the North China Plain, based on the measurements from a rural site. The relative contributions of meteorological factors and anthropogenic emissions are investigated, which provide further insight into the potential causes of the observed trend of surface $\mathrm{O}_{3}$.

\section{Data and methods}

\subsection{Site and measurements}

Surface $\mathrm{O}_{3}$ and ancillary data were collected at the Shangdianzi (SDZ, $40.65^{\circ} \mathrm{N}, 117.10^{\circ} \mathrm{E}, 293.3 \mathrm{~m}$ a.s.1.) station. SDZ is one of the regional Global Atmosphere Watch (GAW) stations, located about $100 \mathrm{~km}$ northeast of suburban of Beijing. The $30 \mathrm{~km}$ radius surrounding the site contains only small villages with a sparse population and insignificant anthropogenic emission sources. The observation facilities are situated on the south slope of a hill, which is surrounded by mountainous areas except in the southwest sector. Fruit trees and corn are grown in the fields surrounding the site. Previous studies (Lin et al., 2008; Xu et al., 2009) suggest that the observations of pollutants at SDZ reflect the regional-scale air quality of North China.

The maximum daily average $8 \mathrm{~h}$ (MDA8) concentrations of $\mathrm{O}_{3}$ were calculated from hourly averages of $\mathrm{O}_{3}$ from October 2003 to June 2015 and are used in the following analysis. To facilitate the analysis, ambient $\mathrm{NO}_{2}$ concentration and temperature measured at SDZ in the surface layer during the same time period were processed to obtain daily averages. Details of the observations and the quality assurance and quality control $(\mathrm{QA} / \mathrm{QC})$ procedures were described by Lin et al. (2008).

\subsection{Analysis methods}

It is well known that meteorology plays an important role in ozone formation and transport. Ground-level ozone concentrations are strongly influenced by fluctuations of meteorological parameters. Therefore, it is difficult to distinguish the trend of ozone related to the change in emissions from that related to meteorological impacts. In order to filter out or minimize the influence of meteorology on ozone levels, a method called Kolmogorov-Zurbenko (KZ) filter (Rao and Zurbenko, 1994) is used to separate data into short-term, seasonal and long-term variations. The KZ filter is based on an 
iterative moving average that removes high frequency variations in the data. The method is briefly described below.

The $\mathrm{KZ}(m, n)$ filter is defined as $n$ applications of a moving average of $m$ points. The moving average can be expressed as

$Y_{i}=\frac{1}{m} \sum_{j=-k}^{k} X_{i+j}$

where $m=2 k+1$, and the calculated $Y_{i}$ becomes the input for the second pass, and so on.

Data filtered by the KZ filter preserve information related to physical processes, whereas data treated by some other techniques may remove unwanted information, but at the same time distort phenomena of interest. Eskridge et al. (1997) compared the KZ filter method with several others, such as wavelet transform, anomalies, etc. and demonstrated that the KZ filter has the same level of accuracy as the wavelet transform method. In addition, the magnitude of the long-term trend estimated by the KZ filter provides estimates with approx. 10 times higher confidence than the other methods. However, the width moving average $(m)$ of the KZ filter with wide windows will dampen sharp breaks of variations. Based on the KZ filter, an adaptive filter was developed by Zurbenko et al. (1996), which dynamically adjusts the width of $m$ according to the rate of change of the process. As the rate of change increases, the $m$ decreases. The modified KZ filter method is applied in this paper. More details on this method can be found in Zurbenko et al. (1996).

Rao et al. (1997) developed a method to separate different phenomena present in time series of both meteorological and ozone data, which have different characteristics such as longterm and short-term variations. Following the method, it is assumed that the time series of ozone can be partitioned as

$O(t)=W(t)+S(t)+e(t)$,

where $O(t)$ is the original time series, $W(t)$ is the mesoscale and synoptic-scale variation, $S(t)$ is the seasonal change, $e(t)$ is the long-term (trend) component. Rao et al. (1997) found that when $\mathrm{KZ}_{15,5}$ and $\mathrm{KZ}_{365,3}$ filters are applied to the raw data, several influences could be removed and the actual variation of ozone at different scales would be obtained. $W(t)$, $S(t)$ and $e(t)$ can be calculated using the following formulae.

$$
\begin{aligned}
& W(t)=O(t)-\mathrm{KZ}_{15,5}, \\
& S(t)=\mathrm{KZ}_{15,5}-\mathrm{KZ}_{365,3}, \\
& e(t)=\mathrm{KZ}_{365,3}
\end{aligned}
$$

The Rao et al. (1997) method was implemented in this work.

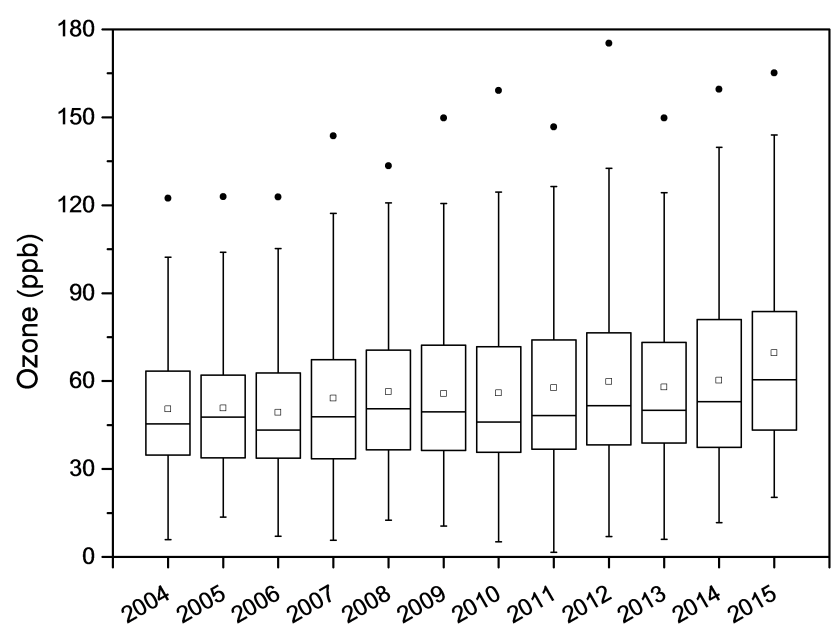

Figure 1. Percentile-box plot of yearly statistics of MDA8 values of ozone at SDZ, in the period of 2004-2015. Boxes depict interquartile range and median; the squares depict the mean; whiskers depict 10th and 90th percentile; dots depict maximum values.

\section{Results and discussion}

\subsection{General characteristics of yearly ozone distribution}

Yearly MDA8 statistics were calculated for 2004-2015 and are presented in Fig. 1. Since the ozone observation at SDZ commenced in October 2003, no reliable yearly MDA8 statistics can be obtained. It is noted that data from 2015 cover only the first 6 months. Although only the first 6 months records in 2015 are used for the statistics, the maximum of the MDA8 values in this year exceeded $160 \mathrm{ppb}$, only second to that in 2012. The yearly average of MDA8 varied from 49.3 to $60.2 \mathrm{ppb}$ during 2004-2014, with a highly significant positive trend $\left(1.05 \pm 0.14\right.$ ppb year $^{-1}, R=0.93$, $P<0.0001)$. We also observed a similar fluctuation of the median value within the range of 43.3 to $53.0 \mathrm{ppb}$, with a positive trend $\left(0.62 \pm 0.20\right.$ ppb year $\left.^{-1}, R=0.72, P<0.05\right)$ from 2004 to 2014. The MDA8 level was relatively stable during 2004-2006, with a maximum of approx. $120 \mathrm{ppb}$. However, the annual maximum value exhibited a dramatic increase from $123 \mathrm{ppb}$ in 2006 to $165 \mathrm{ppb}$ in 2015. This increase coincided with an increase of in the size of the vehicle fleet in eastern China. For example, in Beijing, the number of registered vehicles was 2.30 million in 2004, 2.88 million in 2006, 4.81 million in 2010, and 5.60 million in 2014 (http://www.bjjtgl.gov.cn/jgj/ywsj/index.html). Both the maximum $\mathrm{O}_{3}$ value and the vehicle number increased dramatically in the period 2004-2015. Nevertheless, it is not possible to derive a reliable long-term trend in the median or maximum value solely from the data shown in Fig. 1, nor can we directly attribute the observed changes in surface $\mathrm{O}_{3}$ to the increase in vehicles. 




Figure 2. Separated time series of MDA8 values of ozone at SDZ: (a) the original data; (b) the short-term component, $W(t)$; (c) the seasonal component, $S(t)$; (d) the long-term component, $e(t)$.

\subsection{Ozone time series separated by KZ filter}

The ozone time series (MDA8 value) from the SDZ site was separated using the method described in Sect. 2.2. Figure 2 shows the original time series of MDA8 values (Fig. 2a) and the time series of the separated short-term, seasonal and longterm components (Fig. 2b-d). The original MDA8 exhibits a distinct seasonal variation, with an overlapping of highfrequency noises (Fig. 2a). Removing the short-term component (Fig. 2b) leads to clearer seasonal cycles shown in Fig. 2c. As can be seen in Fig. 2c, there are evident double peaks of ozone during summer in each year, which are not so obvious in the original time series (Fig. 2a). Generally, the double peaks occur in June and September, respectively, and the dip in between occurs in July or August when relatively abundant rainfall damps ozone formation and accumulation. Under the influence of the summer Asian monsoon, rainfall in July and August at SDZ can amount to more than $40 \%$ of the annual rainfall. Figure $2 \mathrm{c}$ also demonstrates some irregularities in the seasonal cycle, particularly the year-toyear changes in the levels of annual maximum, annual minimum and the dip between the double peaks. The seasonal fluctuations have to be accurately removed to get the longterm trend, as data for the trend analysis are required to be independent of season and normally distributed. The shortterm component (Fig. 2b) showed high frequency variations, ranging between -60 and $70 \mathrm{ppb}$, which are composed of noise (or fluctuation) caused by mesoscale and synopticscale meteorological processes. Synoptic-scale events have a timescale from 2 days to 3 weeks, which could be removed by smoothing with the KZ filter for a window size of 15 days and five iterations. To further illustrate the short-term component, a quantile-quantile $(Q-Q)$ plot of $W(t)$ is presented in Fig. 3. The $Q-Q$ plot indicates that $W(t)$ basically obeys

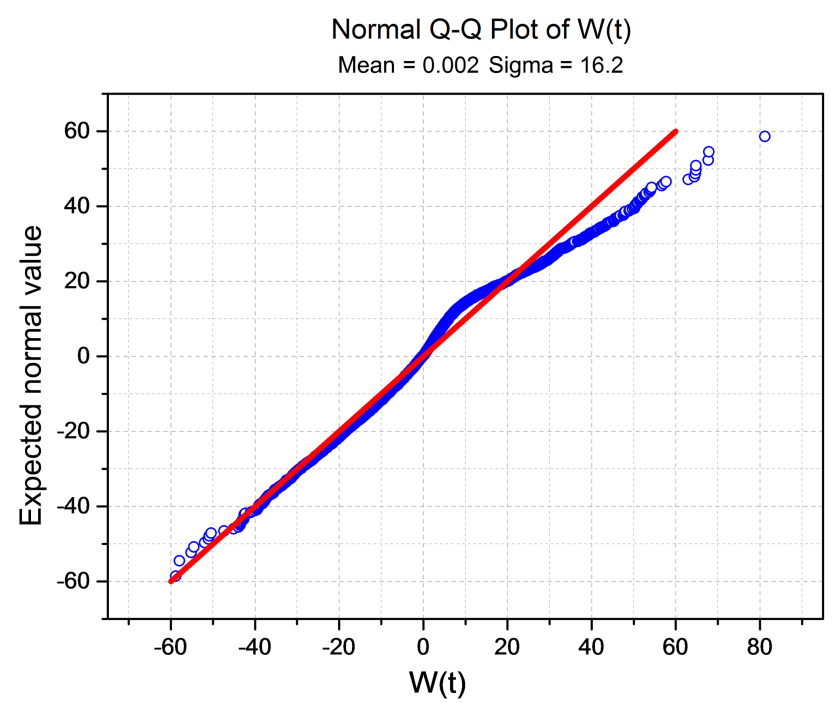

Figure 3. $Q-Q$ plot of the short-term component $W(t)$ for ozone.

a normal distribution, with a mean value of $0.002 \mathrm{ppb}$, suggesting that the $\mathrm{KZ}_{15,5}$ filter effectively removed $W(t)$ from $O(t)$.

Through the previous steps and using the Eqs. (2)-(5), we obtained the long-term trend of MDA8 at SDZ, as shown in Fig. 2d. This long-term trend reveals a rapid increase of the daily high value of surface ozone at the SDZ site in the last decade. It is noteworthy that the increase is not at a stable rate but with large inter-annual variations. Linear regression (not shown) indicates that the average increase rate during 2004-2015 was $1.13 \pm 0.01$ ppb year $^{-1}\left(r^{2}=0.92\right)$. Previous work by Ding et al. (2008) using MOZAIC data obtained a yearly increase of $2 \%$ (about $1 \mathrm{ppb}$ year $^{-1}$ ) of $\mathrm{O}_{3}$ in the boundary layer around Beijing in the period of 1995-2005, which agrees well with our result. Therefore, the greater Beijing area, probably the North China Plain, has been suffering a rapid ozone increase for the last 2 decades.

In view of the air pollution problems, the central government of China issued a revised National Ambient Air Quality Standard (CNAAQS, GB 3095-2012) in 2012, which has taken effect across the country since 1 January 2016 and sets the MDA8 $\mathrm{O}_{3}$ limits to $100 \mu \mathrm{g} \mathrm{m}^{-3}$ (46.7 ppb) and $160 \mu \mathrm{g} \mathrm{m}^{-3}(74.7 \mathrm{ppb})$ for national reserve areas and residence/commercial areas, respectively. As can be seen in Fig. 2a, $\mathrm{O}_{3}$ exceedance would occur quite often in the warm seasons if the new CNAAQS had been implemented.

We also examined the contributions of different components to the total variance of MDA8, which was calculated from the unfiltered data. The contributions of the short-term and seasonal components to the total variance are about 36.4 and $57.6 \%$, respectively. The long-term component accounts for only $2.2 \%$ of the total variance. The covariance terms amount to less than $4 \%$ of the total variance, indicating an effective separation of different components. The long-term 

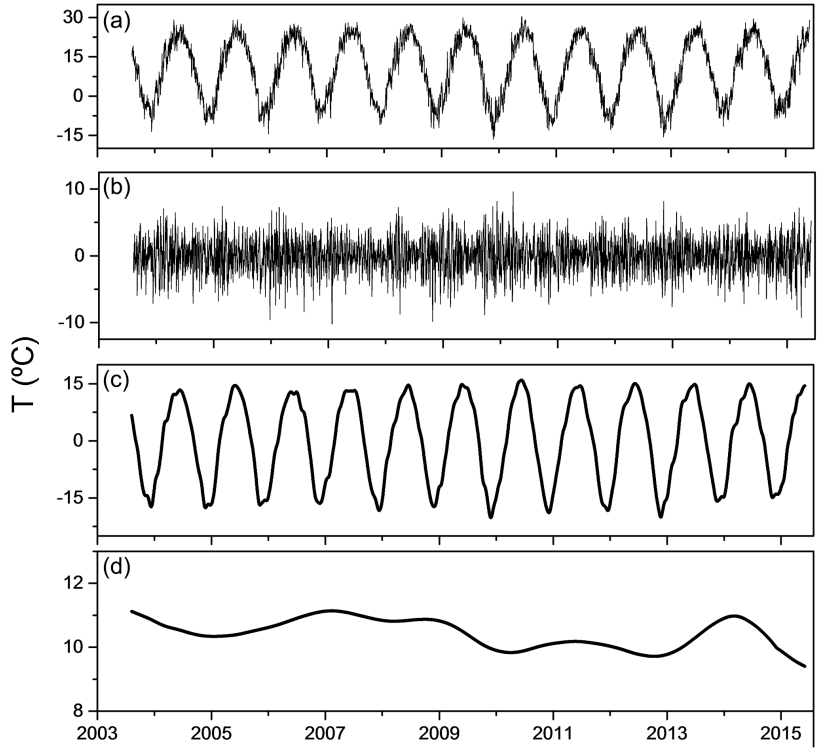

Figure 4. Separated time series of daily mean values of temperature at SDZ: (a) the original data; (b) the short-term component, $W(t)$; (c) the seasonal component, $S(t)$; (d) the long-term component, $e(t)$.

component makes only a much smaller contribution than the other two components, confirming the necessity to clearly separate the short-term and seasonal variations from the data to obtain the long-term trend.

\subsection{Cause analysis}

The long-term trend of the ozone concentration can be caused by the changes of both pollutant emissions and related meteorological variables. Climate variability and circulation shifts may lead to long-term changes of $\mathrm{O}_{3}$ as discussed in Lin et al. (2014; 2015a, b). To assess the influence of precursor emissions on the ozone trend, the meteorological and chemical impacts have to be separated. However, both meteorological and chemical impacts are complicated, not to mention the interactions among meteorology, precursor emissions and photochemical reactions. Therefore, a clear separation of meteorological and chemical impacts is hardly possible purely based on observational data. Nevertheless, apportionment of the $\mathrm{O}_{3}$ trend to precursor emissions and other causes are worthy of further study.

Although many meteorological variables can influence the photochemical formation of $\mathrm{O}_{3}$, the prevailing variable is temperature. The increase of temperature can speed up the photochemical reactions, strengthen the emissions of biogenic VOCs and reduce wind speed, among others (Lin et al., 2001; NRC, 1991; Pusede et al., 2015). In certain regions, temperature is also closely related to the intensity of solar radiation, which plays a critical role in the photochemical formation of $\mathrm{O}_{3}$. Thus, we took temperature as a key me-

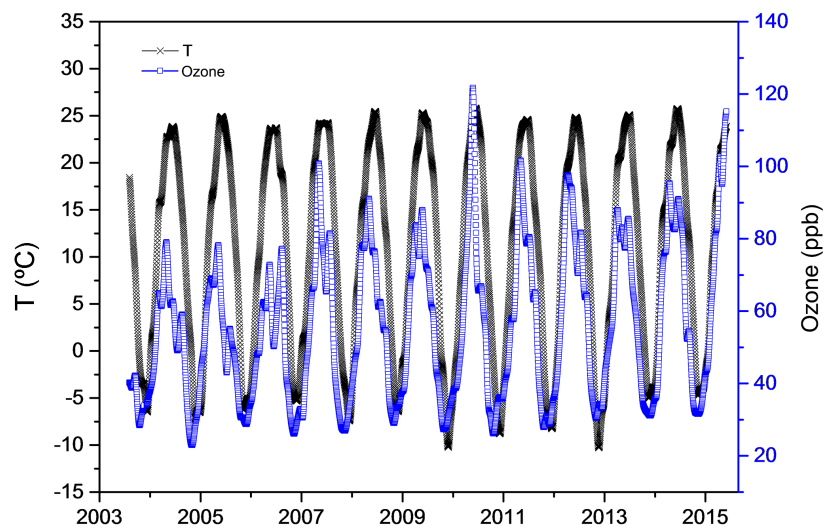

Figure 5. Results of the daily mean temperature and the MDA8 value of ozone after the application of the $\mathrm{KZ}_{15,5}$ filter to the original time series. The results indicate the sum of the seasonal and long-term components.

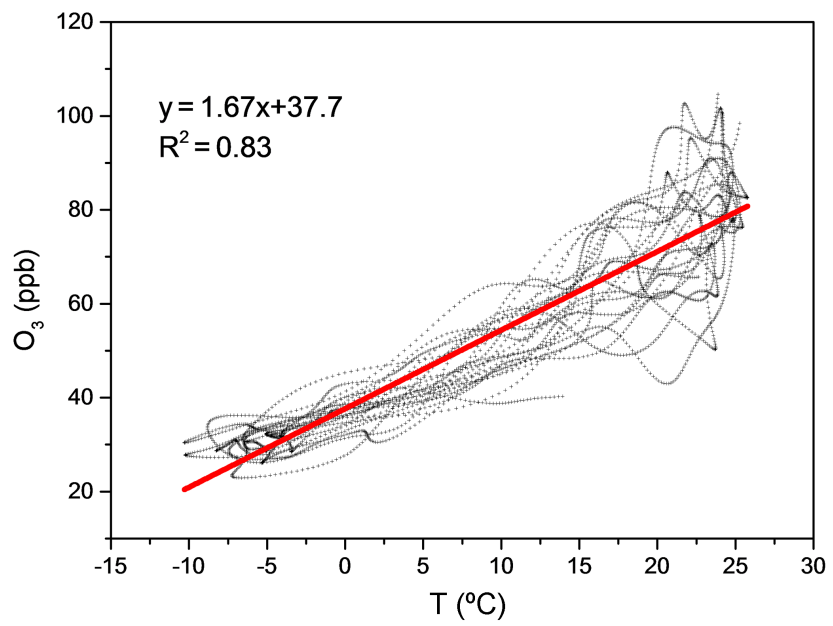

Figure 6. Linear regression fit on the filtered daily maxima of temperature and ozone. Temperature data are lagged by 17 days to ozone data.

teorological parameter and investigated the relationship between $\mathrm{O}_{3}$ and temperature, with the hope to obtain the influence of emission changes on the long-term trend of $\mathrm{O}_{3}$. The initial step was to divide the time series of temperature into three components in Eq. (2), just as done for that of MDA8 (Fig. 2). The results of the different components of temperature are given in Fig. 4. Unlike the trend of MDA8 of $\mathrm{O}_{3}$, the long-term component for temperature at SDZ shows a slight decrease trend $\left(R^{2}=0.015\right)$ (Fig. 4d) and this longterm component accounts only for $0.16 \%$ of the total variance of temperature.

The unfiltered data of $\mathrm{O}_{3}$ and temperature are less correlated $\left(R^{2}=0.50, P<0.0001\right)$, presumably due to the strong influence of the short-term component. Figure 5 compares the derived seasonal cycles of the daily mean temperature (from Fig. 4c) and the MDA8 of $\mathrm{O}_{3}$ (from Fig. 2c). A similar- 


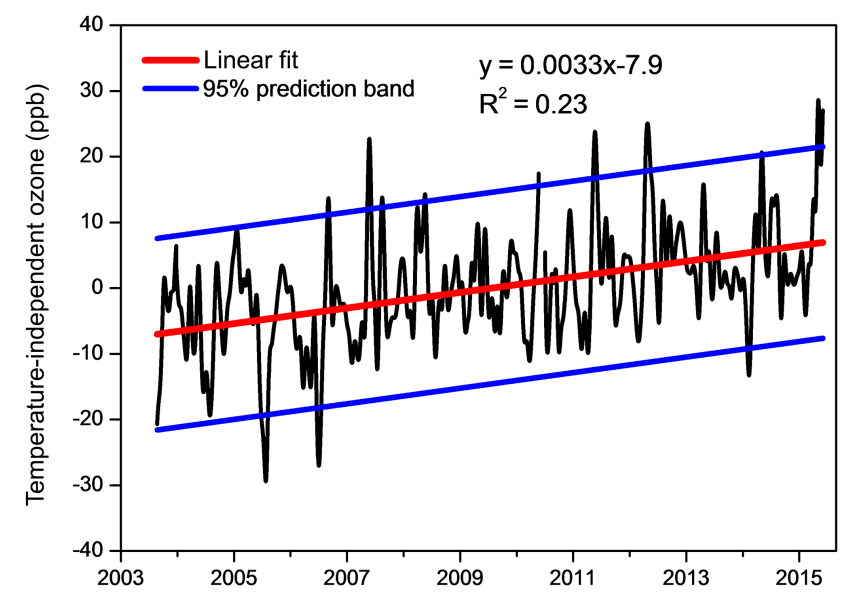

Figure 7. Time series of the noise-free and temperatureindependent ozone. The red line is a linear fit and the blue lines are the $95 \%$ confidence prediction band.

ity is evident between both seasonal cycles. However, there is also a distinct phase lag of the seasonal cycle between $\mathrm{O}_{3}$ and temperature, due to the influence of other processes on the $\mathrm{O}_{3}$ level. Rao et al. (1995) found a similar phase lag of about 3 weeks in the data from the northeastern United States. In our case, the linear correlation between $\mathrm{O}_{3}$ and temperature becomes the strongest $\left(R^{2}=0.83, P<0.0001\right)$ when the temperature data are lagged by 17 days (Fig. 6).

When only considering the influence of temperature, the seasonal and long-term components of $\mathrm{O}_{3}$ could account for $93 \%$ of the total variance at the Cliffside Park, New Jersey (Rao and Zurbenko, 1994), while in our case, it accounts for just $83 \%$ (see $R^{2}$ in Fig. 6). We tried to add more meteorological factors that could affect $\mathrm{O}_{3}$ production, such as solar radiation and relative humidity. However, the correlation was improved by no more than $0.5 \%$. This implies that the changes in emissions might have a more important influence on surface $\mathrm{O}_{3}$ at $\mathrm{SDZ}$ than at Cliffside Park. This view is consistent with the rapid increases in anthropogenic emissions in China (particularly the North China Plain) during the last decade (Mijling et al., 2013).

Assuming that the residual of the total variance of $\mathrm{O}_{3}$, after subtracting the contribution related with temperature, was all caused by pollutant emissions, the long-term trend of $\mathrm{O}_{3}$, attributable to changes in emissions, can be determined by performing a linear regression between time and the noise-free, temperature-independent $\mathrm{O}_{3}$ values $(\varepsilon(t))$, which are derived using Eq. (6):

$O_{k z}(t)=a T_{k z}(t+17)+b+\varepsilon(t)$,

where $O_{k z}(t)$ is the filtered $\mathrm{O}_{3}$ concentration, $T_{k z}(t+17)$ is the filtered temperature lagged by 17 days, $a$ and $b$ are fitted parameters, $\varepsilon(t)$ is the residual of the relationship. Here, $\varepsilon(t)$ reveals the changes in ozone attributable to changes in emissions.

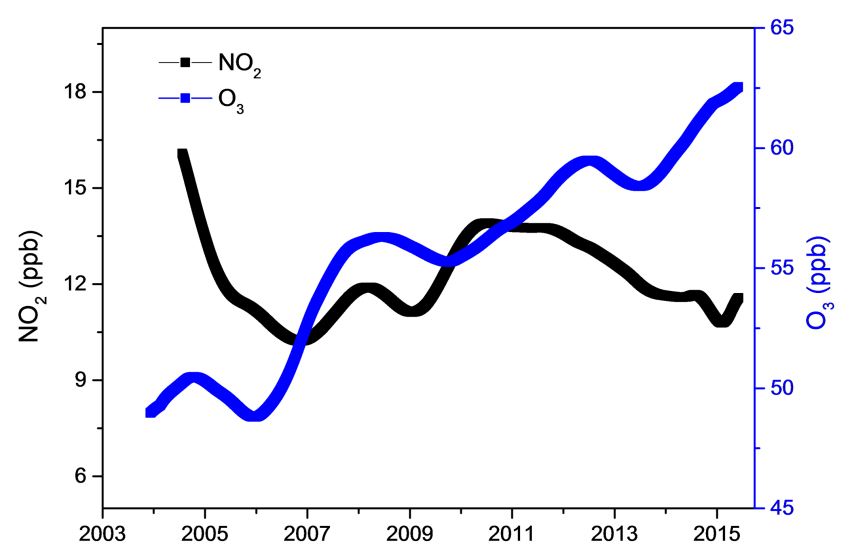

Figure 8. Long-term trends of $\mathrm{NO}_{2}$ and the MDA8 ozone value calculated by $\mathrm{KZ}_{365,3}$.

Figure 7 shows the time series of the noise-free and temperature-independent $\mathrm{O}_{3}$, which is basically equal to the long-term component of $\mathrm{O}_{3}$ only under the influence of emission changes. Most of the data in Fig. 7 are within a $95 \%$ confidence interval band except for some special cases in the summer months. In summer, temperature is not the dominant restricting factor for $\mathrm{O}_{3}$ production compared to other factors, such as rainfall and precursor concentrations. Substantial negative influences occurring in 2005 and 2006 can be explained by stronger impact of Asian summer monsoon on surface $\mathrm{O}_{3}$ (Lin et al., 2008). The results in Fig. 7 indicate that the influence of emission has been varying substantially but with an average increase rate of $1.19 \pm 0.03$ ppb year $^{-1}$. This increase rate is very close to the average long-term trend of MDA8 of $\mathrm{O}_{3}\left(1.13 \pm 0.01\right.$ ppb year $\left.^{-1}\right)$ in Fig. $2 \mathrm{~d}$, implying that the increase of $\mathrm{O}_{3}$ in the period of 2003-2015 could be mainly attributed to the emission changes and that the meteorological factors had only a tiny negative influence. Jaffe and Ray (2007) also found that the temperature change had little influence on long-term ozone trends in the western US.

Some studies suggested that the trends of surface $\mathrm{O}_{3}$ at the similar latitude as SDZ could be attributed partly to the reduced titration by NO (Chou et al., 2006; Itano et al., 2007). In order to assess the effect of changing NO titration on the long-term trend of $\mathrm{O}_{3}$, we examined the long-term measurements of $\mathrm{NO}_{2}$ at SDZ in the period of 2004-2015. A comparison of the long-term trend of $\mathrm{O}_{3}$ with that of $\mathrm{NO}_{2}$, which was also extracted using the previous methods, is displayed in Fig. 8. The evolution of the $\mathrm{NO}_{2}$ trend can be divided into three stages, i.e., a substantial decrease of $\mathrm{NO}_{2}$ occurring during the first 3 years, followed by a small increase in the period of 2007-2010 and finally a gradual decrease in the period of 2011-2015. The large decrease of $\mathrm{NO}_{2}$ in the period of 2004-2006 corresponded to the control of coal consumption around Beijing, especially for the Olympic Games in 2008 (Zhang et al., 2010; Gao et al., 2011) and to the relocation of the Capital Steel and Iron Company, which was one 
of the largest industrial sources in Beijing. The $\mathrm{NO}_{2}$ increase from 10.2 to $13.5 \mathrm{ppb}$ between 2007 and 2010 corresponded with the rapid increase in the number of vehicles in Beijing from 3.1 million to 4.8 million (http://www.bjjtgl.gov.cn/jgj/ ywsj/index.html). From 2011 to 2015, the new standards for vehicle emissions and measures for reduction of $\mathrm{NO}_{x}$ emission from power plants were implemented, which may have helped to reduce the $\mathrm{NO}_{2}$ concentration. The long-term trends of $\mathrm{O}_{3}$ and $\mathrm{NO}_{2}$ given in Fig. 7 do not show any coincidence. Therefore, it is nearly impossible that the reduced NO titration had led to the increase of surface $\mathrm{O}_{3}$ at SDZ. Previous studies (Ge et al., 2010; 2012) showed that the ozone production efficiency at SDZ varied in values from 0.2 to 21.1, with an average of 4.9, implying that ozone formation at SDZ could be more sensitive to VOCs than to $\mathrm{NO}_{x}$. Accordingly, we believe that the changes of $\mathrm{VOC}$ emissions and the ratio of VOCs to $\mathrm{NO}_{x}$ might have caused the increase of surface $\mathrm{O}_{3}$ observed at SDZ. Unfortunately, no systematic VOC observations are available from the SDZ site so that we cannot prove this supposition conclusive. However, a large increase in the anthropogenic emissions of non-methane hydrocarbon (NMHC) can be inferred from the Multiresolution Emission Inventory for China (MEIC) (http://www.meicmodel.org) for Beijing in the period of 2004-2012, which supports our view, although the emission data are questioned by a recent study (Wang et al., 2015).

\section{Summary}

We separated the time series of maximum daily average $8 \mathrm{~h}$ (MDA8) concentration of surface $\mathrm{O}_{3}$ observed at SDZ in the period of 2003-2015 into various spectral components using a modified KZ filter. This separation has led to a better understanding of the variation of surface $\mathrm{O}_{3}$ at the site and its relationships with the meteorological and precursor variables, enabling us to unravel the trend of $\mathrm{O}_{3}$ from the original data containing noises and seasonality, and to estimate the contribution of changes of precursor emissions to the trend. Our analysis reveals that the short-term, seasonal and long-term components of $\mathrm{O}_{3}$ data from the SDZ site accounted for 36.4, 57.6 and $2.2 \%$ of the total variance, respectively.

It is found that the MDA8 of $\mathrm{O}_{3}$ at the site north of eastern China has undergone a significant increase in the period of 2003-2015, at an average rate of $1.13 \pm 0.01 \mathrm{ppb}$ year $^{-1}$. Together with the reported yearly increase rate of $2 \%$ in the lower tropospheric $\mathrm{O}_{3}$ around Beijing in the period of 1995-2005 (Ding et al., 2008), we conclude that the north part of eastern China (i.e., the North China Plain) may have been suffering a rapid increase in the $\mathrm{O}_{3}$ level for at least 2 decades. By eliminating the influence of air temperature, we found that the observed increase of surface $\mathrm{O}_{3}$ in the period of 2003-2015 was mainly induced by the emission changes, and the meteorological factors exerted only a tiny negative influence. Our result also indicates that the change of VOC emissions might have played a more important role in the $\mathrm{O}_{3}$ increase than the effect of $\mathrm{NO}_{x}$.

Because fine particulate pollution has been very severe in eastern China, the central government of China has implemented several measures to control $\mathrm{PM}_{2.5}$ pollution, including reductions of both $\mathrm{NO}_{x}$ and VOCs. This, however, risks further $\mathrm{O}_{3}$ increases as a VOCs to $\mathrm{NO}_{x}$ ratio more favorable to ozone production may be reached. Thus, further studies are needed to trace the ozone trend and its influence in eastern China.

Acknowledgements. The authors would like to thank the staff of the Shangdianzi station for their excellent work. This research is supported by the National Science Foundation of China (41475135, 41330422), Beijing Natural Science Foundation (8132025, 8152018), CCSF201505. We also thank the referees and editor for their constructive suggestions.

Edited by: J. B. Burkholder

\section{References}

Brown-Steiner, B. and Hess, P.: Asian influence on surface ozone in the United States: A comparison of chemistry, seasonality, and transport mechanisms, J. Geophys. Res., 116, D17309, doi:10.1029/2011JD015846, 2011.

Chan, C. Y., Chan, L. Y., and Harris, J. M.: Urban and background trend in 1984-1999 subtropical Hong Kong, South China, Ozone: Science and Engineering, 25, 513-522, doi:10.1080/01919510390481829, 2003.

Chou, C. C. K., Liu, S. C., Lin, C. Y., Shiu, C. J., and Chang, K. H.: The trend of surface ozone in Taipei, Taiwan, and its causes: Implications for ozone control strategies, Atmos. Environ., 40, 3898-3908, doi:10.1016/j.atmosenv.2006.02.018, 2006.

Cooper, O. R., Parrish, D. D., Ziemke, J., Balashov, N. V., Cupeiro, M., Galbally, I. E., Gilge, S., Horowitz, L., Jensen, N. R., Lamarque, J.-F., Naik, V., Oltmans, S. J., Schwab, J., Shindell, D. T., Thompson, A. M., Thouret, V., Wang, Y., and Zbinden, R. M.: Global distribution and trends of tropospheric ozone: An observation-based review, Elementa: Science of the Anthropocene, 2, 1-28, doi:10.12952/journal.elementa.000029, 2014.

Derwent, R. G., Utembe, S. R., Jenkin, M. E., and Shallcross, D. E.: Tropospheric ozone production regions and the intercontinental origins of surface ozone over Europe, Atmos. Environ., 112, 216-224, 2015.

Ding, A. J., Wang, T., Thouret, V., Cammas, J.-P., and Nédélec, P.: Tropospheric ozone climatology over Beijing: analysis of aircraft data from the MOZAIC program, Atmos. Chem. Phys., 8, 1-13, doi:10.5194/acp-8-1-2008, 2008.

Eskridge, R. E., Ku, J. Y., Rao, S. T., Porter, P. S., and Zurbenko, I. G.: Separating Different Scales of Motion in Time Series of Meteorological Variables, B. Am. Meteorol. Soc., 78, 1473-1483, doi:10.1175/1520-0477(1997)078<1473:SDSOMI>2.0.CO;2, 1997.

Gao, Y., Liu, X., Zhao, C., and Zhang, M.: Emission controls versus meteorological conditions in determining aerosol concentra- 
tions in Beijing during the 2008 Olympic Games, Atmos. Chem. Phys., 11, 12437-12451, doi:10.5194/acp-11-12437-2011, 2011. Ge, B. Z., Xu, X. B., Lin, W. L., and Wang, Y.: Observational study of ozone production efficiency at the Shangdianzi Regional Background Station, Environ. Sci., 31, 1444-1450, 2010 (in Chinese with English abstract).

Ge, B. Z., Xu, X. B., Lin, W. L., Li, J., and Wang, Z. F.: Impact of the regional transport of urban Beijing pollutants on downwind areas in summer: ozone production efficiency analysis, Tellus B, 64, 17348, doi:10.3402/tellusb.v64i0.17348, 2012.

Granier, C., Bessagnet, B., Bond, T., D’Angiola, A., van der Gon, H. D., Gregory, J., Frost, G. J., Heil, A., Kaiser, J. W., Kinne, S., Klimont, Z., Kloster, S., Lamarque, J. F., Liousse, C., Masui, T., Meleux, F., Mieville, A., Ohara, T., Raut, J. C., Riahi, K., Schultz, M. G., Smith, S. J., Thompson, A., Aardenne, J. V., Werf, G. R., and Vuuren, D. P.: Evolution of anthropogenic and biomass burning emissions of air pollutants at global and regional scales during the 1980-2010 period, Climatic Change, 109, 163-190, doi:10.1007/s10584-011-0154-1,2011.

Hauglustaine, D. A. and Brasseur, G.: Evolution of tropospheric ozone under anthropogenic activities and associated radiative forcing of climate, J. Geophys. Res., 106, 32337-32360, 2003.

Hess, P. G. and Zbinden, R.: Stratospheric impact on tropospheric ozone variability and trends: 1990-2009, Atmos. Chem. Phys., 13, 649-674, doi:10.5194/acp-13-649-2013, 2013.

IPCC: Climate Change 2013 - The Physical Science Basis, Cambridge University Press, Cambridge, 1552 pp., 2013.

Itano, Y., Bandow, H., Takenaka, N., Saitoh, Y., Asayama, A., and Fukuyama, J.: Impact of $\mathrm{NO}_{x}$ reduction on long-term ozone trends in an urban atmosphere, Sci. Total Environ., 379, 46-55, doi:10.1016/j.scitotenv.2007.01.079, 2007.

Jaffe, D. and Ray, J.: Increase in surface ozone at rural sites in the western US, Atmos. Environ., 41, 5452-5463, doi:10.1016/j.atmosenv.2007.02.034, 2007.

Kurokawa, J., Ohara, T., Morikawa, T., Hanayama, S., JanssensMaenhout, G., Fukui, T., Kawashima, K., and Akimoto, H.: Emissions of air pollutants and greenhouse gases over Asian regions during 2000-2008: Regional Emission inventory in ASia (REAS) version 2, Atmos. Chem. Phys., 13, 11019-11058, doi:10.5194/acp-13-11019-2013, 2013.

Lee, S.-H., Akimoto, H., Nakane, H., and Kurnosenko, S.: Lower tropospheric ozone trend observed in 1989-1997 in Okinawa, Japan, Geophys. Res. Lett., 25, 1637-1640, 1998.

Lin, C., Jacob, D. J., and Fiore, A. M.: Trends in exceedances of the ozone air quality standard in the continental United States, 1980-1998, Atmos. Environ., 35, 3217-3228, 2001.

Lin, M., Fiore, A. M., Horowitz, L. W., Cooper, O. R., Naik, V., Holloway, J., Johnson, B. J., Middlebrook, A. M., Oltmans, S. J., Pollack, I. B., Ryerson, T. B., Warner, J. X., Wiedinmyer, C., Wilson, J., and Wyman, B.: Transport of Asian ozone pollution into surface air over the western United States in spring, J. Geophys. Res., 117, 183-204, 2012.

Lin, M., Horowitz, L. W., Oltmans, S. J., Fiore, A. M., and Fan, S.: Tropospheric ozone trends at Manna Loa Observatory tied to decadal climate variability, Nat. Geosci., 7, 136-143, doi:10.1038/NGEO2066, 2014.

Lin, M., Fiore, A. M., Horowitz, L. W., Langford, A. O., Oltmans, S. J., Tarasick, D., and Reider, H. E.: Climate variability modulates western US ozone air quality in spring via deep stratospheric intrusions, Nat. Commun., 6, 7105, doi:10.1038/ncomms8105, 2015a.

Lin, M., Horowitz, L. W., Cooper, O. R., Tarasick, D., Conley, S., Iraci, L. T., Johnson, B., Leblanc, T., Petropavlovskikh, I., and Yates, E. L.: Revisiting the evidence of increasing springtime ozone mixing ratios in the free troposphere over western North America, Geophys. Res. Lett., 42, 8719-8728, doi:10.1002/2015GL065311, 2015b.

Lin, W., Xu, X., Zhang, X., and Tang, J.: Contributions of pollutants from North China Plain to surface ozone at the Shangdianzi GAW Station, Atmos. Chem. Phys., 8, 5889-5898, doi:10.5194/acp-8-5889-2008, 2008.

Mijling, B., van der A, R. J., and Zhang, Q.: Regional nitrogen oxides emission trends in East Asia observed from space, Atmos. Chem. Phys., 13, 12003-12012, doi:10.5194/acp-1312003-2013, 2013.

Monks, P. S., Archibald, A. T., Colette, A., Cooper, O., Coyle, M., Derwent, R., Fowler, D., Granier, C., Law, K. S., Mills, G. E., Stevenson, D. S., Tarasova, O., Thouret, V., von Schneidemesser, E., Sommariva, R., Wild, O., and Williams, M. L.: Tropospheric ozone and its precursors from the urban to the global scale from air quality to short-lived climate forcer, Atmos. Chem. Phys., 15, 8889-8973, doi:10.5194/acp-15-8889-2015, 2015.

NRC (National Research Council): Rethinking the Ozone Problem in Urban and Regional Air Pollution, National Academy Press, Washington, D.C., 1991.

Ohara, T., Akimoto, H., Kurokawa, J., Horii, N., Yamaji, K., Yan, X., and Hayasaka, T.: An Asian emission inventory of anthropogenic emission sources for the period 1980-2020, Atmos. Chem. Phys., 7, 4419-4444, doi:10.5194/acp-7-4419-2007, 2007.

Oltmans, S., Lefohn, A. S., Harris, J. M., Galbally, I., Scheel, H. E., Bodeker, G., Brunke, E., Claude, H., Tarasick, D., Johnson, B. J., Simmonds, P., Shadwick, D., Anlauf, K., Hayden, K., Schmidlin, F., Fujimoto, T., Akagi, K., Meyer, C., Nichol, S., Davies, J., Redondas, A., and Cuevaso, E.: Long-term changes in tropospheric ozone, Atmos. Environ., 40, 3156-3173, 2006.

Oltmans, S. J., Lefohn, A. S., Shadwick, D., Harris, J. M., Scheel, H. E., Galbally, I., Tarasick, D.W., Johnson, B.J., Brunke, E.G., Claude, H., Zeng, G., Nichol, S., Schmidlin, F., Davies, J., Cuevas, E., Redondas, A., Naoen, H., Nakano, T., and Kawasato, T.: Recent tropospheric ozone changes-a pattern dominated by slow or no growth, Atmos. Environ., 67, 331-351, 2013.

Ordonez, C., Brunner, D., Staehelin, J., Hadjinicolaou, P., Pyle, J. A., Jonas, M., Wernli, H., and Prevot, A. S. H.: Strong influence of lowermost stratospheric ozone on lower tropospheric background ozone changes over Europe, Geophys. Res. Lett., 34, L07805, doi:10.1029/2006GL029113, 2007.

Parrish, D. D., Law, K. S., Staehelin, J., Derwent, R., Cooper, O. R., Tanimoto, H., Volz-Thomas, A., Gilge, S., Scheel, H.-E., Steinbacher, M., and Chan, E.: Long-term changes in lower tropospheric baseline ozone concentrations at northern mid-latitudes, Atmos. Chem. Phys., 12, 11485-11504, doi:10.5194/acp-1211485-2012, 2012.

Pausata, F. S. R., Pozzoli, L., Vignati, E., and Dentener, F. J.: North Atlantic Oscillation and tropospheric ozone variability in Europe: model analysis and measurements intercomparison, Atmos. Chem. Phys., 12, 6357-6376, doi:10.5194/acp-12-63572012, 2012. 
Penkett, S. A.: Indications and causes of ozone increase in the troposphere, in: Rowland, F. S. and Isaksen, I. S. A., The Changing Atmosphere, J. Wiley\&Sons, p. 91, 1988.

Pusede, S. E., Steiner, A. L., and Cohen R. C.: Temperature and Recent Trends in the Chemistry of Continental Surface Ozone, Chem. Rev., 115, 3898-3918, 2015.

Rao, S. T. and Zurbenko, I. G.: Detecting and Tracking Changes in Ozone Air Quality, Air Waste, 44, 1089-1092, doi:10.1080/10473289.1994.10467303, 1994.

Rao, S. T., Zalewsky, E., and Zurbenko, I. G.: Determining Temporal and Spatial Variations in Ozone Air Quality, J. Air Waste Manage., 45, 57-61, doi:10.1080/10473289.1995.10467342, 1995.

Rao, S. T., Zurbenko, I. G., Neagu, R., Porter, P. S., Ku, J. Y., and Henry, R. F.: Space and Time Scales in Ambient Ozone Data, B. Am. Meteorol. Soc., 78, 2153-2166, 1997.

Richter, A., Burrows, J. P., Nub, H., Granier, C., and Neimeier, U.: Increase in tropospheric nitrogen dioxide over China observed from space, Nature, 437, 129-132, doi:10.1038/nature04092, 2005.

Streets, D. G., Tsai, N. Y., Akimoto, H., and Oka, K.: Trends in emissions of acidifying species in Asia, 1985-1997, Water Air Soil Poll., 130, 187-192, doi:10.1023/A:1013883628877, 2001.

Verstraeten, W. W., Neu, J. L., Williams, J. E., Bowman, K. W., Worden, J. R., Boersma, K. F.: Rapid increases in tropospheric ozone production and export from China, Nat. Geosci., 8, 690695, doi:10.1038/ngeo2493, 2015.

Wang, M., Shao, M., Chen, W., Lu, S., Liu, Y., Yuan, B., Zhang, Q., Zhang, Q., Chang, C.-C., Wang, B., Zeng, L., Hu, M., Yang, Y., and Li, Y.: Trends of non-methane hydrocarbons (NMHC) emissions in Beijing during 2002-2013, Atmos. Chem. Phys., 15, 1489-1502, doi:10.5194/acp-15-1489-2015, 2015.

Wang, T., Wei, X. L., Ding, A. J., Poon, C. N., Lam, K. S., Li, Y. S., Chan, L. Y., and Anson, M.: Increasing surface ozone concentrations in the background atmosphere of Southern China, 19942007, Atmos. Chem. Phys., 9, 6217-6227, doi:10.5194/acp-96217-2009, 2009.
Xu, W. Y., Lin, W. L., Xu, X. B., Tang, J., Huang, J. Q., Wu, H., and Zhang, X. C.: Long-term trends of surface ozone and its influencing factors at the Mt. Waliguan GAW station, China - Part 1: Overall trends and characteristics, Atmos. Chem. Phys. Discuss., 15, 30987-31024, doi:10.5194/acpd-15-30987-2015, 2015.

Xu, X., Lin, W., Wang, T., Yan, P., Tang, J., Meng, Z., and Wang, Y.: Long-term trend of surface ozone at a regional background station in eastern China 1991-2006: enhanced variability, Atmos. Chem. Phys., 8, 2595-2607, doi:10.5194/acp-8-2595-2008, 2008.

Xu, X. B. and Lin, W. L.: Trends of Tropospheric Ozone over China Based on Satellite Data (1979-2005), Advances in Climate Change Research, 2, 43-48, doi:10.3724/SP.J.1248.2011.00043, 2011.

Xu, X. B., Liu, X. W., and Lin, W. L.: Impacts of air parcel transport on the concentrations of trace gases at regional background stations, J. Appl. Meteorol. Sci., 20, 656-664, 2009 (in Chinese with English abstract).

Zhang, Q. H., Zhang, J. P., and Xue, H. W.: The challenge of improving visibility in Beijing, Atmos. Chem. Phys., 10, 78217827, doi:10.5194/acp-10-7821-2010, 2010.

Zhang, X. Y., Zhang, P., Zhang, Y., Li, X. J., and Qiu, H.: The trend, seasonal cycle, and sources of tropospheric $\mathrm{NO}_{2}$ over China during 1996-2006 based on satellite measurement, Sci. China Ser. D, 50, 1877-1884, 2007.

Zurbenko, I., Chen, J., Rao, S. T., Ku, J. Y., Gui, R., and Eskridge, R. E.: Detecting discontinuities in time series of upper air data: Demonstration of an adaptive filter technique, J. Climate, 9, 3548-3560, 1996. 